\title{
Promotion of Unopposed Elections in Haryana Panchayats: A Visionary Approach
}

\author{
Dr. S. L. Kundu \\ Assistant Professor in Political Science, M.K.J.K. College, Rohtak (Haryana)-India
}

\begin{abstract}
The success of democracy depends upon free and fair elections. Elections serve as a means of communication between the public and government. It is a process through which leaders are selected by vote for a political office. The 73rd Constitutional Amendment Act, 1992 marked a new era in the democratic set up of the country as it created Panchayati Raj Institutions (PRIs) as third tier of the federal set up. It gives considerable attention to the nature of elections for the three levels of panchayati raj institutions. Direct elections are specified for seats at all levels. The act provides for one additional potential avenue of representation and accountability of local government. Unopposed elections are the reflection of mature democratic trend.
\end{abstract}

Keywords: Election, Haryana Panchayati Raj, Panches, Panchayat Samit, Sarpanch, Unopposed Elections, Zila Parishad.

\section{Introduction}

Elections constitute an indispensable political activity and indicate the general will of the common masses as well as provide legitimacy to the government. They are the important mechanism for checking the use of governmental arbitrary power. Election is a process through which the political opinion of the people is shaped. Through elections a modern state creates amongst its citizens a sense of participation in public affairs, and in making the people aware of their rights. So, election is an essential for a vibrant democracy. Panchayats considered as mini republics. The success, growth and even survival of the soverign, secular and socialist India depends upon the elected panchayats. These institutions of self government are assigned powers and responsibilities for executing twin mission of economic development and social justice.

In pursuance of the $73^{\text {rd }}$ Constitutional amendment, the Haryana Government enacted the Haryana Panchayati Raj Act, 1994. The Sarpanch and panches are directly elected by gram sabha from amongst its voters by secret ballot. The panchayati raj rules state that there shall be six panches for a gram panchayat having population up to five hundred and for every additional five hundred populations or fraction thereof one extra seat shall be provided subject to a maximum of twenty seats. If a fraction forms part of the number of a seat or the office computed the number of seats or offices shall be increased to the next higher number in case the fraction consists of half or more of a seat or office and the fraction shall be ignored in case it consists of less than half of a seat or the office. ${ }^{[1]}$

Haryana Panchayati Raj (Election) Rules, 1994 section 37 depicts that any one candidate (whose nomination paper is found valid) remains after the date and time fixed for withdrawal of nomination paper then the duty of the Returning Officer (Panchayat) is to declare the candidate elected and inform the State Election Commissioner through District Election Officer (Panchayat). ${ }^{[2]}$

Unopposed election at the grassroots level is the most important aspect for democratic organizations and promotional schemes for encouraging this trend is the reflection of positivism in the present political scenario. Haryana Chief Minister Ch. Bhupinder Singh Hooda has emphasized on the promotion of unopposed elections in panchayats by providing special grant to these bodies. Under the provisions of above said grant, the village panchayats are classified population wise into three categories. The classified first, second and third categories are comprising upto 1500 population villages, above 1500 to 4000 population and above 4000 population villages respectively. In the first, second and third categories where the whole panchayat including sarpanch is elected unopposed the provisions of the grant are Rs. One lakh, two lakh and three lakh respectively. If only panches are elected unopposed from first, second and third categories the provided amount is Rs. 75000, 1.5lakh and 2.5 lakh respectively. When only a sarpanch of a village is elected unopposed then the provisions of the grant are Rs. 50000, one lakh and 1.5 lakh for respective category. ${ }^{[3]}$ This is great step of Haryana Government regarding strengthening the democracy in the State as well as become a touch bearer for Indian democratic practices. 


\section{First Haryana Panchayati Raj Elections, 1994}

The first panchayat general election was held in December, 1994 in three phases i.e. December 11, 15 and 19,1994 . At that time there were 16 zila parishads, 110 panchayat samitis and 5958 gram panchayats in Haryana. Total 54159 panches including 17928(33.10\%) women, 11793(21.77\%) scheduled castes and $5648(10.43 \%)$ backward class panches were elected in this election. Regarding panchayat samitis, total 2418 members including 807 (33.37\%) women, 519(21.46\%) scheduled castes and 110(4.55\%) backward class members were elected. Total 303 zila parishad members including 101(33.33\%) women, 64(21.12\%) scheduled caste and 16(5.28\%) backward class members were elected in this election.Total 5958 sarpanches including 1994 women and 1199 scheduled castes, 110 chairpersons of panchayat samitis including 38 women and 21 scheduled castes and 16 chairpersons of zila parishad including 5 women and 3 scheduled castes were elected for public welfare. So, no data regarding unopposed elected representatives of PRIs is available of this election. [4]

\section{Second Haryana Panchayati Raj Elections, 2000}

The second PRIs general elections were due in December, 1999, so, the voter list was prepared on June07, 1999 but this list was challenged in Punjab \& Haryana High Court by Ambala district voters. Ultimately, the elections were held on $12^{\text {th }}$ and $16^{\text {th }}$ days of March, 2000. At the time of elections, there were 19 zila parishads, 114 panchayat samitis and 6035 gram panchayats in the State. ${ }^{[5]}$ The State Election Commission issued a notification for holding the second general election to PRIs in three phases and later modified it into two phases. The dates i.e. 22 and 29 March, 2000 were fixed but again changed to 12 and 16 March, 2000 due to annual examinations of Board of School Education Haryana. Total 85, 90, 880 voters casted their votes at 15, 998 polling stations to elect 6,035 sarpanches and 54,764 panches out of which $701(12 \%)$ and 30,674 (56\%) were elected unopposed respectively. ${ }^{[6]}$ Regarding panchayat samiti, total 2426 seats were fixed for members and $426(18 \%)$ were elected unopposed. In case of zila parishad, out of 314 seats only $45(14 \%)$ candidates were elected unopposed. In gram panchayats, panchayat samitis \& zila parishads the representation of women was $18037(32.99 \%), 842(34.65 \%)$ and $108(34.39 \%)$ respectively. For the posts of sarpanches, chairpersons of panchayat samiti and zila parishads, the representation of women was significant i.e. $2009(33.29 \%), 52$ $(45.61 \%)$ and $7(36.84 \%)$ respectively. ${ }^{[7]}$

\section{Third Haryana Panchayati Raj Elections, 2005}

The State Election Commission fixed the schedule for conducting the third PRIs general elections into two phases. In the first phase (April3,2005), there were 26817 panches, 2737 sarpanches, 1256 panchayat samiti members and 164 members of zila parishad were elected from 53 blocks of 18 districts. In the second phase (Apri19,2005), total 33459 panches, 3443 sarpanches, 1577 panchayat samiti members and 220 members of zila parishad were elected from 66 blocks of 19 districts. ${ }^{[8]}$ In Haryana Panchayati Raj election, 2005, total 36645 (60.8\%) panches were elected unopposed. The Panchkula district was at the first place with $75 \%$ and Karnal district was in the last with $44.6 \%$ regarding unopposed elected panches. In case of sarpanches, total $473(7.7 \%)$ seats were filled through unopposed elections. Total $302(10.7 \%)$ and 2(0.5\%) members of panchayat samiti and zila parishad respectively were elected unopposed. ${ }^{[9]}$

\section{Fourth Haryana Panchayati Raj Elections, 2010}

The Fourth panchayati raj general elections, 2010 were held in two phases i.e.June6 \& 12, 2010. Total 22931(39.02\%) panches were elected unopposed out of 58765 panches. In this regard, Panchkula district secured first position with 65.36\%, Ambala and Fatehabad districts hold second and Third positions respectively. The district Panipat is the backward district regarding unopposed elections with $25.85 \%$. If we consider the statistical data gender wise and categorywise then we find that total $9724(16.55 \%)$ male and 6724 (11.44\%) female unopposed elected panches belongs to general category, 2004(3.41\%) female and 1846 (3.14\%) male unopposed elected panches belongs to scheduled castes and $2492(4.24 \%)$ male and $141(0.34 \%)$ female backward class panches are elected unopposed in this election. Only 175 (2.87\%) out of 6083 sarpanches and $35(1.26 \%)$ out of 2772 members of panchayat samiti are elected unopposed. Overall 62 panchayats including sarpanches and 90 panchayats excluding sarpanches are elected unopposed in Haryana. ${ }^{[10]}$

Total 8860 women panch elected unopposed in panchayat general elections, 2010. In this regard Bhiwani district holds first position with 725 women panch followed by Jind (595) and Ambala (581). Faridabad district lages behind with 150 women panch in this hierarchy. There are total 228 women panch belong to general category who are elected unopposed from other than their reserved seats and Rewari district secured first position with 52 women panch in this regard followed by Sirsa (26),Bhiwani (26) and Sonipat(18) but Karnal and Kurukshetra districts on the backward line with only 2 women panch each. In case of scheduled castes, total $60 \mathrm{sc}$ women panch are elected unopposed from sc male reserved seats and Ambala district with 12 women panch is at the first place in this regard followed by Mahindergarh (06), Sonipat (06) and Karnal (05) 
but four districts (Faridabad, Jhajjar, Mewat and Rohtak) have no representation in this regard. It is analysed that the total strength of the unopposed women panch who are elected from other than their reserved seats is 288. In this context Rewari district has more representation with 56 women followed by Sirsa(28), Bhiwani (27), Sonipat(24) and the Mewat district has lowest representation with only 2 women panchayat members. ${ }^{[1]}$ The below given table higlights a District-wise View of Panches, Sarpanches and Panchayat Samiti Members Elected Unopposed in Fourth Haryana PRIs Elections, 2010.

\section{A District-Wise View Of Panches, Sarpanches And Panchayat Samiti Members Elected Unopposed In} Fourth Haryana Pris Elections, 2010

\begin{tabular}{|l|c|c|c|c|c|c|}
\hline \multirow{2}{*}{ Representatives } & \multicolumn{2}{|c|}{ Panches } & \multicolumn{2}{c|}{ Sarpanches } & \multicolumn{2}{c|}{ Panchayat Samiti Members } \\
\cline { 2 - 7 } & Total & Unopposed Elected & Total & $\begin{array}{c}\text { Unopposed } \\
\text { Elected }\end{array}$ & Total & Unopposed Elected \\
\hline Ambala & 3131 & $1530(48.86 \%)$ & 405 & $20(4.94 \%)$ & 119 & $3(2.52 \%)$ \\
\hline Bhiwani & 4544 & $1866(41.06 \%)$ & 460 & $5(1.23 \%)$ & 211 & $2(0.94 \%)$ \\
\hline Fatehabad & 1142 & $385(33.71 \%)$ & 111 & $5(4.50 \%)$ & 57 & -- \\
\hline Gurgaon & 2482 & $1170(47.14 \%)$ & 244 & $18(7.37 \%)$ & 130 & $3(2.31 \%)$ \\
\hline Hisar & 1818 & $853(46.92 \%)$ & 210 & $11(5.24 \%)$ & 86 & $2(2.32 \%)$ \\
\hline Jhajjar & 3715 & $1365(36.74 \%)$ & 309 & $4(1.29 \%)$ & 217 & $5(2.30 \%)$ \\
\hline Jind & 2597 & $1066(41.04 \%)$ & 249 & $1(0.40 \%)$ & 118 & $1(0.84 \%)$ \\
\hline Kaithal & 27326 & $1524(45.82 \%)$ & 300 & $8(2.66 \%)$ & 172 & $2(1.16 \%)$ \\
\hline Karnal & 3595 & $1193(43.11 \%)$ & 270 & $22(8.15 \%)$ & 141 & $2(1.42 \%)$ \\
\hline Kurukshetra & 3151 & $970(26.98 \%)$ & 372 & $11(2.95 \%)$ & 174 & $1(0.57 \%)$ \\
\hline Panchkula & 898 & $587(65.36 \%)$ & 121 & $10(8.26 \%)$ & 40 & $1(0.85 \%)$ \\
\hline Panipat & 1907 & $493(25.85 \%)$ & 167 & $1(0.59 \%)$ & 111 & $3(7.5 \%)$ \\
\hline Mahendergarh & 3134 & $928(29.61 \%)$ & 344 & $1(0.29 \%)$ & 140 & $1(0.71 \%)$ \\
\hline Mewat & 2950 & $1100(37.28 \%)$ & 311 & $8(2.57 \%)$ & 128 & $2(1.56 \%)$ \\
\hline Rewari & 2998 & $1034(34.48 \%)$ & 351 & $6(1.71 \%)$ & 107 & $1(0.93 \%)$ \\
\hline Rohtak & 1771 & $525(29.64 \%)$ & 141 & $2(1.42 \%)$ & 123 & $2(1.62 \%)$ \\
\hline Sirsa & 3389 & $1278(37.71 \%)$ & 334 & $6(1.79 \%)$ & 170 & $5(2.94 \%)$ \\
\hline Sonepat & 3525 & $1382(39.20 \%)$ & 323 & $3(0.93 \%)$ & 177 & $2(1.13 \%)$ \\
\hline Yamunanagar & 3467 & $1384(39.92 \%)$ & 441 & $16(3.63 \%)$ & 122 & $1(0.82 \%)$ \\
\hline Total & 58765 & $22931(39.02 \%)$ & 6083 & $184(3.02 \%)$ & 2772 & $43(1.55 \%)$ \\
\hline
\end{tabular}

SOURCE: State Election Commission Panchayat Statistics, 2010.

It is clear from above table that total 22931 (39.02\%) panches were elected unopposed out of 58765 panches in Haryana. Panchkula district secures first position with $65.36 \%$ regarding unopposed elected panches followed by Ambala (48.86\%) and Fatehabad (47.14\%) districts. The Panipat district is in the last with $25.85 \%$ in this hierarchy. Total 184(3.02\%) sarpanches have been elected unopposed in Haryana out of 6083 sarpanches. District Kaithal is at the first place with $22(8.15 \%)$ unopposed elected sarpanches followed by Ambala20(4.94\%) and Fatehabad-18(7.37\%) districts but Mahendergarh-1(0.29\%), Jhajjar-1(0.40\%) and Panipat$1(0.59 \%)$ districts have lowest representation in this regard. Total $43(1.55 \%)$ members out of 2772 members of panchayat samiti have been elected unopposed in Haryana. The districts Sirsa and Hisar got first place with 5 members each followed by Ambala, Fatehabad, Palwal and Panipat districts with 3 members each and Faridabad is the only district which has no representation in this regard.

\section{Main Observations}

The main observations regarding unopposed elections of fourth PRIs general elections, 2010 are:

$>$ Out of total 140 gram panchayats where all panches and sarpanches have been elected unopposed, Kaithal district has 18 such panchayats followed by Kurukshetra (17) but Jhajjar and Rohtak districts don't have any such gram panchayat means no panchayat have been elected unopposed including sarpanches in Jhajjar and Rohtak districts.

$>$ There are total 176 gram panchayats, where all members have been elected unopposed means without sarpanches. Ambala district is at the top with 25 such gram panchayats followed by Yamunanagar (18) and the district Panipat has no representation in this regard.

$>$ Total 45 gram panchayats have elected unopposed sarpanches means where only sarpanches elected unopposed but not all members. In this context, Ambala district is at the top with 6 gram panchayats 
followed by Fatehabad and Kurukshetra with 5 sapanches and Panchkula, Panipat, Mahendergarh, Mewat and Sonepat districts have no such unopposed elected sarpanch.

$>$ In Haryana 6 villages boycotted 2010 panchayat elections, Jind district is at the top with 2 villages i.e. Sangatpura of Jind block and Singhwal of Narwana block followed by Bhiwani district (Bapoda village of Bhiwani block), Kaithal district (Karora village of Rajound block),Panipat district (Khukhrana of Madlauda block) and Rewari district (Ram singh Pura village of Bawal block) each have one village in this regard.

$>$ All the seats (reserved and unreserved) have been won by women candidates in Lalheri village of Ganaur block in Sonepat district. ${ }^{[12]}$

$>$ Three backward class male panches have been elected unopposed from SC reserved seats in Gurgaon district.

$>$ Total 16 general category male panchayat members have been elected unopposed from women reserved seats in Rewari district.

\section{Conclusion}

After analysis of this data, it may be concluded that this trend of unopposed elections may lead to reduce the election violence, booth capturing, election criminalization, flow of liquor, money and vote sharing unhealthy trends at the time of elections and election expenditure etc. If we consider the only case of reduction or saving the election expenditure then the legal expenditure limits are Rs. 5000, Rs. 20000, Rs. 50000 and Rs. One lakh for panch, sarpanch, member panchayat samiti and zila parishad respectively. We can calculate the expenditure incurred on the elections of panchayati raj bodies according to above said provisions and find the saved amount in crores.

Unopposed elections are the reflection of matured democratic trend in Haryana local governance process. So, such special grant decision which is taken by the Haryana Government not only saves the candidate money but also preserves the social unity, promote bhaichara culture, avoid court disputes, develop the positive thinking in the village community and reduce the administrative work also. Some suggestions may be helpful for strengthening this trend. The provisions of the grant should be extended to the individual member of these institutions because of the less possibility to elect the whole panchayat unopposed. This support should be provided to panchayat samitis, zila parishads and urban local bodies also. There should be a separate ward fund for such types of grants. In the last but not lease, it is the result of positive mind set of the Haryana Government headed by Ch. Bhupinder Singh Hooda. Due to this the Haryana may be a role model for India as well as for world also.

\section{References}

[1] Rule 3, Haryana Panchayati Raj Election Rules 1994, vide Haryana Government Notification No. GSR 56/HA 11/94/209/94 dated August 24, 1994.

[2] Section 37, Haryana Panchayati Raj (Election) Rules, 1994, ibid.

[3] Dainik Jagran, April 16, 2010, p.1

[4] R.K.Kundu and S.L.Kundu, Unopposed Elections in Haryana Panchayati Raj Institutions: An Analysis of Fourth General Elections, 2010, (Coimbatore: Asian Review of Social Sciences, An International Peer- Reviewed Journal on Social Sciences, 1(1) JanuaryJune, 2012, 10.

[5] Government of Haryana, Report of State Election Commission Haryana2000, Chandigarh, p. 10.

[6] Government of Haryana, Report of State Election Commission Haryana1994-2004, Chandigarh, pp. 102-103.

[7] Government of Haryana, Report of $2^{\text {nd }}$ State Finance Commission Haryana, Chandigarh, September, $2004,58$.

[8] Government of Haryana, Report of State Election Commission Haryana, Chandigarh: 2005, 38.

[9] Government of Haryana, Report of State Election Commission Haryana, Chandigarh: 2005, 22-24.

[10] R.K.Kundu and S.L.Kundu, Unopposed Elections in Haryana Panchayati Raj Institutions: An Analysis of Fourth General Elections, 2010, (Coimbatore: Asian Review of Social Sciences, An International Peer- Reviewed Journal on Social Sciences, 1(1) JanuaryJune, 2012, 10.

[11] Government of Haryana, Statistics of State Election Commission Haryana, Chandigarh: 2010 Panchayat Elections.

[12] R.K.Kundu \& S.L.Kundu, Women Empowerment and Haryana Panchayat Elections, 2010: An Analysis of New Trends, (Rohtak: RMS Journal of Management and IT, Special Volume on Haryana: Society, Polity \& Economy), December, $2011,115$. 